Revista Iberoamericana, Vol. LXXVII, Núm. 235, Abril-Junio 2011, 425-439

\title{
NANCY MOREJÓN Y LA HISTORIA DE LA MUJER CUBANA: LA OTRA CARA DE LA MONEDA
}

\author{
POR \\ Claudette Williams \\ University of the West Indies
}

Nacida en 1944, Nancy Morejón, principal poeta afrocubana, pertenece a la segunda generación de escritores que surgieron después de la revolución castrista de 1959. Su poesía, de perfil mayormente apolítica durante los años sesenta, comenzó a abordar temas sociales y políticos de una manera más formal a partir de los años setenta, cuando la Revolución puso su sello ideológico en su representación de la experiencia cubana. Al igual que la mayoría de los escritores e historiadores poscoloniales, Morejón ha asumido la tarea de desmantelar las versiones dominantes de la historia colonial. Más específicamente, su perspectiva individual se acopla al clima revisionista vigente en Cuba durante los setenta. Después de un período de valoración inicial que siguió a la Revolución en los sesenta, se dedicó mucha energía intelectual y artística en la década de los setenta a la reescritura de la historia nacional para darle el color de la nueva ideología revolucionaria.

Las composiciones poéticas de Morejón a partir de este período ilustran el concepto socialista de una nación cubana unida y de una sociedad ideal en donde se borran distinciones de raza, clase y género. Aunque su enfoque en el tema racial evita el fundamentalismo afrocéntrico, una innegable sensibilidad étnica se encuentra en aquellos poemas que recuerdan a familiares o que se dedican a otros individuos de origen africano. También ha escrito poemas que tematizan la historia de la esclavitud, por ejemplo 'Madrigal para cimarrones' de Octubre imprescindible (1982) y 'Negro' de la colección Piedra pulida (1986).

Su inserción de la mujer africana o de origen africano en el discurso literario cubano le ha granjeado la simpatía tanto de los feministas como de los nacionalistas afrocéntricos. Sin dominar su voz poética, la sensibilidad feminista de Morejón se manifiesta mediante diferentes formas oblicuas, entre ellas, el valerse de figuras femeninas en el papel protagónico y como creadoras de la historia. Entre sus composiciones más conocidas se encuentran las que presentan a mujeres negras de la vida real, por ejemplo, su madre, tía y abuela, además de sujetos femeninos ficticios como las 
protagonistas de 'Mujer negra’ (1975) y ‘Amo a mi amo’ (1986). ${ }^{1}$ Ambos poemas se destacan por su perspectiva de la historia femenina cubana. En un repertorio poético cuya significación es muchas veces alusiva, si no elusiva, dichos poemas, de lectura bastante fácil, son notables por su accesibilidad. Estos poemas se han sometido al análisis crítico casi exhaustivo. ${ }^{2}$ Las siguientes páginas proponen adentrarse en los significados asequibles al lector cuando los dos textos se ubican en la encrucijada de los discursos feministas, poscoloniales y posrevolucionarios, interpretándolos como ejemplares de subversión de las metanarrativas de las tradiciones históricas y literarias. En el discurso de la posmodernidad, la palabra 'metanarrativa' o 'gran narrativa' se utiliza para referirse a la historia de una cultura o sociedad contada por sí misma. El posmodernismo, según Mary Klages es "the critique of grand narratives, the awareness that such narratives serve to mask the contradictions and instabilities that are inherent in any social organization or practice” (169).

Al publicarse estos poemas, la revaloración del papel de la mujer como participante en la historia se había convertido en función normal de la historiografía revisionista. Previamente, el tema había captado la imaginación de otro artista cubano, el cineasta Humberto Solás en Lucía, su largometraje de 1968. A través de la historia de tres mujeres con el nombre genérico de Lucía, la película resume medio siglo de historia cubana en tres momentos políticos claves: la Guerra de Independencia que comenzó en 1895, la revolución efímera de 1932 que puso fin a la dictadura de Gerardo Machado y el triunfo de la revolución socialista en la década de los sesenta. Lucía sirve de punto comparativo para 'Mujer negra' en cuanto el poema se aproxima a la película con su protagonista asimismo genérica y la gran extensión de su alcance histórico. Tanto la poeta como el cineasta enfocan en la mujer común a quien había olvidado o excluido la tradición heroica de la historia cubana. Aunados por su visión benéfica de la transformación revolucionaria, se separan los dos por cuestiones de percepción y representación.

Los orígenes históricos en la película de Solás se asocian con la mujer criolla blanca durante la época colonial tardía. Al escoger a la mujer de origen africano como protagonista, Morejón se remonta a un pasado aun más lejano, trazando su trayectoria desde la esclavitud en adelante y sus esfuerzos por conquistar un lugar merecido en la historia nacional. Los dos personajes cumplen funciones representativas semejantes.

1 Las citas de ambos poemas son de la siguiente colección de la autora: Richard trajo su flauta y otros poemas (1999), edición de Mario Benedetti.

2 En la colección de ensayos Singular like a Bird: The Art of Nancy Morejón, homenaje a la poeta que editó Miriam DeCosta-Willis, los dos poemas son comentados por Lorna V. Williams, Mariela Gutiérrez y Janet Hampton. Para un análisis minucioso de ‘Amo a mi amo’ véase también el artículo de Conrad James.

Revista Iberoamericana, Vol. LXXVII, Núm. 235, Abril-Junio 2010, $425-439$
ISSN 2154-4794 (Electrónico) 
Como encarnación de un sujeto transhistórico, el personaje del poema puede considerarse una homóloga afrocubana de las Lucías de Solás (criollas blancas las dos primeras y mestiza la tercera). Y aunque recalca su papel en el proyecto histórico nacional, la poeta lo logra sin implicación de separatismo racial.

No es de maravillar que, en la historiografía cubana posrevolucionaria, la esclavitud haya venido a considerarse como manifestación temprana de la lucha secular de liberación que culminó en la Revolución castrista. En 'Mujer negra’ se encuentran índices históricos, pero en forma poética y con el recurso de verbos en primera persona, lo cual le asigna a la mujer el papel de creadora tanto de su propia historia como de la de su país. De suma importancia para la interpretación del poema es la idea del voluntarismo que caracteriza todas las experiencias vitales y cada etapa de la historia de la mujer afrocubana.

Mientras que el sendero de la Lucía simbólica de Solás está marcada objetivamente con fechas específicas y referentes históricos, el personaje de 'Mujer negra' transita por un tiempo subjetivo y por espacios líricos:

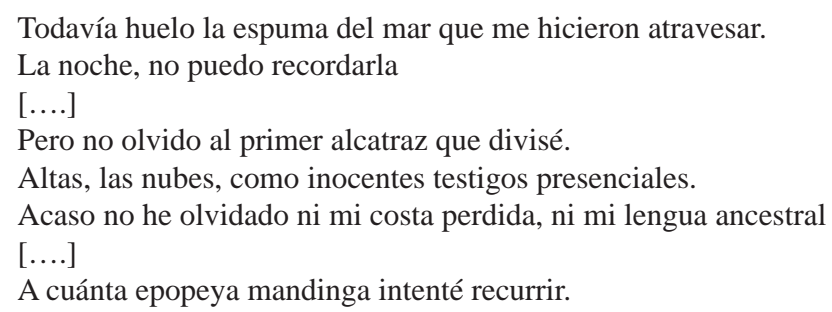

Me rebelé. (46)

Con sólo una alusión muy sutil al pasado preesclavista y una referencia aun más vaga de los horrores del viaje desde África, (tema frecuente de la historia y la literatura), da por sentado su fortaleza y su capacidad para adaptarse, dos características que han asegurado su supervivencia. Esta propensión psíquica es evidente en el mismo momento de su llegada al Caribe y, específicamente, al nombrar la espuma blanca del mar, las nubes blancas en el cielo y el alcatraz, ave marina grande de plumaje blanco en el horizonte. Estas imágenes transmiten su percepción del paisaje caribeño como un mundo brillante, superando así, si bien por inferencia, las bodegas tenebrosas de los barcos negreros y las profundidades oscuras del océano Atlántico, timba de incontables africanos esclavizados. A la manera de su representación del viaje transatlántico, el olvido deliberado de las historias de un pasado africano heroico (emblematizado en la "epopeya mandinga”), proporciona una alternativa para una de las metanarrativas del universo preesclavista, idealizado en el discurso literario poscolonial.

ISSN 0034-9631 (Impreso) 
Escrito aproximadamente una década más tarde, ‘Amo a mi amo’ puede considerarse como compañero natural de 'Mujer negra', para el cual sirve de complemento y contraste. Como el anterior, este poema se adhiere a la tradición poscolonial de reescribir la historia desde una nueva perspectiva. En cada poema la realidad se representa por medio de una conciencia y una voz femenina negra. La esclavitud, en 'Mujer negra,' forma parte de una saga histórica que abarca más de cuatro siglos. Dentro de este marco diacrónico la protagonista africana se transforma en seguida en cubana criolla. 'Amo a mi amo' por contraste, amplía un momento microcósmico de la historia contada en el primer poema: la coexistencia del esclavista y la mujer esclavizada. El abuso sexual de esta mujer por su amo constituye otra metanarrativa del discurso antiesclavista colonial. ${ }^{3}$ Este modelo dominante es el que se invoca en 'Mujer negra'. Suprimiendo los detalles, el poema registra, tácitamente pero sin ambigüedad, la cosificación y violación de la mujer. Sus relaciones con el amo no superan el sistema clásico de poder: no existe una distinción entre su función laboral de costurera y su papel sexual y reproductivo como madre de su hijo. Su violación, aunque silenciada, se esboza en: "Su Merced me compró en una plaza. / Bordé la casaca de Su Merced y un hijo / macho le parí' (46). En estas líneas el personaje demuestra la frialdad de su encuentro sexual (refiriéndose al amo con el título de "Su Merced") y, por otra parte, su desconexión del hijo que pare insinúa la práctica de separar a los niños mulatos de sus madres esclavizadas. No obstante, se niega a narrar el trauma; prefiere en cambio concentrarse en los actos constructivos a los cuales se dedica como autora de su propia historia y de la nación. Así 'Mujer negra' invoca y desplaza simultáneamente la metanarrativa de explotación sexual, substituyendo el discurso de mujer-víctima desamparada por el discurso de mujer-figura dinámica.

Donde el primer poema concibe a la mujer negra sobre todo como símbolo, 'Amo a mi amo' cuenta la historia de una esclava de carne y hueso. El segundo poema es la autobiografía confesional de un sujeto humano con toda la complejidad que esto implica. El personaje sirve para colocar en primer plano una de las ironías olvidadas de la esclavitud: los casos de relaciones amorosas entre esclavistas y esclavizadas. En contraste con el discurso desapasionado de 'Mujer negra', Morejón recurre al lirismo romántico en ‘Amo a mi amo’ para transmitir una perspectiva íntima de amor recíproco. El título casi herético del poema, con su juego de palabras, raya en la presunción de masoquismo de parte de la esclava; postula lo que sería, al parecer de los feministas radicales por lo menos, la idea inconcebiblemente perversa de que una esclava pueda amar a su opresor. La primera parte de su relato a duras penas implica el abuso o la

\footnotetext{
3 Francisco (Anselmo Suárez y Romero, 1839), Petrona y Rosalía (Félix Tanco y Bosmeniel, 1839), El negro Francisco (Antonio Zambrana, 1875) son las más famosas de las novelas antiesclavistas cubanas de la época colonial que tematizan este abuso.

Revista Iberoamericana, Vol. LXXVII, Núm. 235, Abril-Junio 2010, $425-439$
ISSN 2154-4794 (Electrónico)
} 
explotación sexual que se ha normalizado en las metanarrativas antiesclavistas. La mujer confiesa su amor por su amo e implica el amor de éste, a su vez, por ella. El suyo es un trato que rebasa los límites de lo sexual.

Su historia pasa por varias etapas, cada una centrada en un modo de ser y de pensar diferente. La voz lírica de la primera etapa narra su vida sentimental con detalle amoroso, acentuando los gestos eróticos que ella prodiga a su amo. Contrastando con el desapego emocional de la primera protagonista y su referencia impersonal a su amo como "Su Merced" aparecen las connotaciones de identificación afectiva de la segunda protagonista con el hombre a quien ella llama "mi amo". El título, reiterado con regularidad anafórica como estribillo en la primera estrofa, crea un efecto de crescendo en el que cada declaración amplifica y matiza la expresión amorosa:

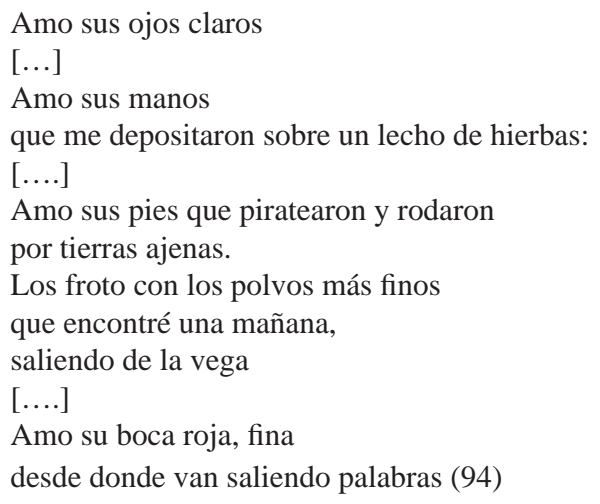

Cada atributo físico de su amo atrae a la mujer: sus manos como instrumentos del amor, sus pies de pirata como encarnación de la energía masculina, su boca como tesoro de canciones e historias. El tema laboral en 'Mujer negra' reaparece aquí, pero el personaje lo vive como placer, como parte de un ritual de amor: ella enciende su fuego diario, unta sus oídos con miel, acaricia sus pies, y le refresca el cuerpo en una ceremonia erótica. Más que un modo de coexistencia caracterizado por el abuso, sus relaciones dan fe de un intercambio de ternura y pasión:

\section{Amo sus manos}

que me depositaron sobre un lecho de hierbas:

Mi amo muerde y subyuga.

Me cuenta historias sigilosas mientras

abanico todo su cuerpo cundido de llagas y balazos (94)

ISSN 0034-9631 (Impreso) 
Su amo-amante la acuesta suavemente, (gesto que corresponde a las expresiones amorosas de ella) y le cuenta historias secretas mientras ella le refresca el cuerpo. Como el título enigmático, la frase "mi amo muerde y subyuga" asume el matiz suavizador de la frase anterior ("sus manos / que me depositaron sobre un lecho de hierbas") y de la subsiguiente ("Me cuenta historias sigilosas") disolviendo así la polarización predador/presa y haciendo alusión a la ironía del potencial placer del dolor. A fin de cuentas el autorretrato de la mujer y la representación de su rol contrastan con el cliché popular de cosificación y abuso sexual normalizado en la ficción antiesclavista también vislumbrado en 'Mujer negra'.

Muchos estudios poscoloniales sobre la esclavitud se han centrado más en los esclavizados y no tanto en los esclavistas. Las representaciones unidimensionales de éstos también han sido muy corrientes. En 'Amo a mi amo' el retrato de la mujer esclavizada en términos no estereotipados tiene su paralelo en la imagen del amo. A diferencia de la figura esbozada del amo de sangre noble en 'Mujer negra,' este amo-pirata tiene un carácter definido y se le atribuyen cualidades y acciones que hacen que el amor de su esclava parezca merecido y no perverso. Humanizado por las canciones, las historias y la música con las cuales él la entretiene, su amo es todo menos desalmado. Tampoco se puede decir que los sentimientos entre ellos corren en una sola dirección; para el amo ella no es un mero objeto a poseer, ni un ser inferior. Su relato tiene resabios de intercambio y mutualidad. La diferencia lingüística que los separa no logra desanimar en ellos la voluntad de comunicarse; se hablan, aunque en dos idiomas mutuamente incomprensibles. Además, su intercambio amoroso potencia una comunicación sin palabras.

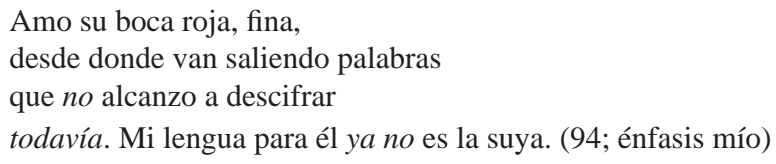

La falta de comunicación aludida en estos versos puede referirse no tan sólo a lo que James (161) denomina choque cultural sino también a la posibilidad de rapprochement lingüístico y cultural. Las frases "no... todavía” y “ya no" en los versos arriba citados presagian un futuro de transculturación (término que posteriormente utilizará Fernando Ortiz para conceptualizar el proceso) o la interpenetración de las culturas europeas y africanas que dio lugar a la hibridación ahora declarada característica esencial de la identidad nacional cubana.

Aparece, sutilmente, un vacío irónico en la representación de la fase romántica de estas relaciones: la autora crea un desacuerdo entre el lector y la protagonista del poema. Aquél tal vez sienta repugnancia por el amo-pirata que una vez pillaba en tierras ajenas,

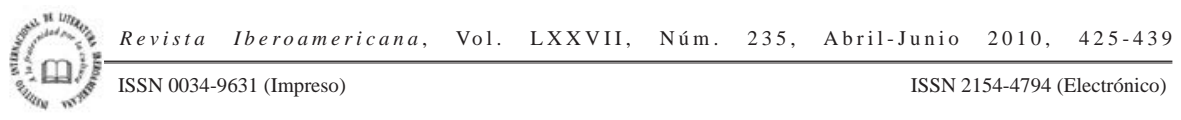


pero esto no basta para manchar su reputación ante la esclava; su imagen amorosa no se enturbia ante los ojos de ella. Incluso hay una sugerencia de admiración sin reproche por las hazañas de su héroe-amante. Así sigue intacto el panorama romántico de esta primera estrofa.

Sin embargo, a Morejón no se le puede tachar de cómplice de la ideología esclavista, pues si bien sincrónica, la perspectiva de ‘Amo a mi amo’ no es la de una foto estática. Su dedicación incondicional al principio, a pesar de ser genuina, es circunstancial. No sólo se reconoce la posible base consensual de la relación erótica entre los dos sino también se imagina cómo y por qué este acercamiento pudo haber sido insostenible bajo el sistema de poder general de la sociedad esclavista. La segunda sección del poema, que consiste en una sola línea, rompe el panorama romántico precedente señalando el descontento y la pérdida de inocencia y abriendo el paso a la siguiente distinción entre el mundo idílico del romance individual y el mundo brutal del abuso general de los esclavizados.

Según lo observado por Conrad James (159), ‘Amo a mi amo’presenta la experiencia de la mujer esclavizada como modelo de resistencia; sin embargo, ella no es el modelo clásico porque su resistencia no es ni instintiva ni primordial. Tampoco es el resultado de su experiencia personal. Lo que la identifica es que su antagonismo se produce con el despertar de su conciencia social y que el deber social viene a restar valor a la satisfacción personal. Reemplazando el efecto sedativo del canto y las fábulas del amo se escucha la voz inquietante de concientización del guardiero esclavo. Por él la mujer se entera de que su ángel tiene un lado diabólico y que es tan capaz de violencia como de ternura. Ahora resulta que su amor por él tiene que ver con la cara que él le ha mostrado. Tolerante de sus hazañas como pirata en una tierra desconocida, es sólo al percibir de cerca la capacidad maligna de su amo que reviste su situación de sentido político. Su amor está trabado por su conocimiento de los azotes sufridos por los demás esclavos en manos de su amante. Sólo la ignorancia la hace dichosa; el conocimiento la deja incómoda. Con el nuevo conocimiento viene una nueva sensibilidad.

Esto lleva al preguntar retórico de la siguiente sección donde el tono cambia de tranquilo a urgente con la articulación anafórica de su descontento y odio emparejándose con la expresión anafórica de su amor en la primera sección. El desconcierto que amar a su amo pudo haber causado al lector ahora se transmite a la mujer que ya no puede sentirse a gusto con su ser aculturado, representado por los atavíos europeos (bata, encajes). La lengua en que le habla el amo, antes dulce y calma, ahora le suena hostil; y no es sólo su propio malestar que siente esta esclava sino también el de sus hermanas desamparadas:

Revista Iberoamericana, Vol. LXXVII, Núm. 235, Abril-Junio 2010, $425-439$
ISSN 0034-9631 (Impreso) 


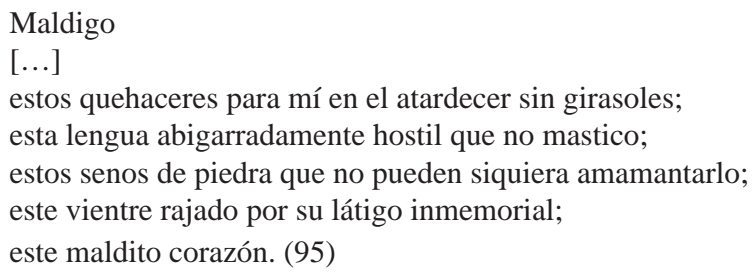

Como veremos más adelante, esta relación flexible con su amo contrasta con el inconformismo tenaz del personaje de 'Mujer negra'.

Aun así la suya no es una concientización exenta de problemas; sirve para matizar y disminuir su amor, pero también va acompañada de una disyuntiva previamente inexistente: el conflicto entre el corazón y la cabeza, entre lo ideológicamente correcto y la inclinación humana natural. Con un conocimiento recién adquirido no puede continuar su amor incondicional. Pero tampoco es posible la transformación mágica de su amor en odio. Bien que la declaración "[m]aldigo .... este maldito corazón” demuestra odio a sí misma por amar a su opresor, también le da a la vivencia del amor un aire espontáneo, como sentimiento de un corazón caprichoso. El personaje insiste en esta idea de una manera gráfica con la imagen de su amor que crece intransigente como las malas hierbas:

Mi amor es como la maleza que cubre la dotación, única posesión inexpugnable mía. (95)

Más que una transformación psíquica, la mujer sufre una crisis de conciencia: la angustia de la ambivalencia moral y emocional. Morejón capta esta vacilación con el uso del verbo amar en tiempo presente en las líneas siguientes:

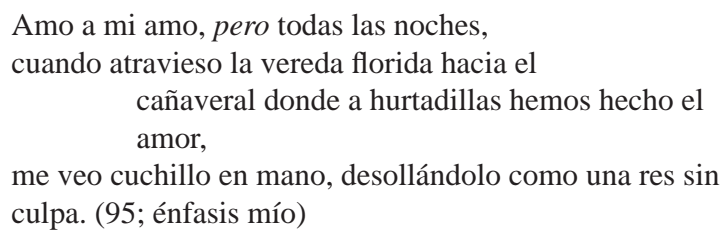

Con la imposibilidad de un retorno a la ignorancia dichosa del pasado romántico o de la renuncia absoluta de su amor, tiene que conformarse con un ajuste psíquico y emocional que permite la coexistencia del amor y el odio en una tensión sin resolver, como lo indican los puntos suspensivos con los que se cierra el poema. En este final abierto estriba la esencia del poema de Morejón, cuya intención no es proponer una

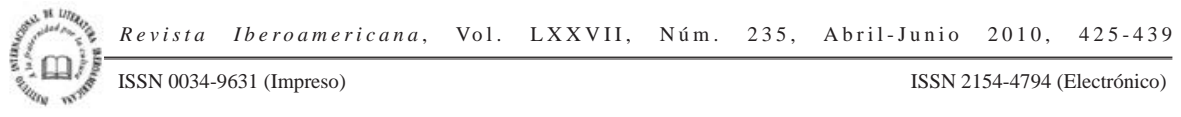


resolución sino obligar al lector a contemplar la ambigüedad y la diversidad de las relaciones entre esclavizado y esclavizante; entre estos dos no existen ni amores ni conflicto sin complicaciones. Esta tensión sin resolver recuerda la escena al final de la película de Solás donde el hecho de que la protagonista reafirma su amor por su marido no se presenta como incompatible con el rechazo, a la vez, de su actitud machista.

El tema de la venganza, presente en ambos poemas, anima la cuarta sección de 'Amo a mi amo'. Al imaginarse la esclava imponiendo un castigo sangriento al amo, otra voz substituye la voz del guardiero, esta vez la voz de los tambores y las campanas que la llaman a integrarse a la lucha de los otros esclavos para librarse de sus cadenas. El poema termina apropiadamente en el momento en que ella cede a la llamada de la represalia, cuya ejecución queda pendiente al final, a la vez que los puntos suspensivos nutren la especulación de que su ambivalencia quede sin resolverse.

Una comparación con la venganza del personaje de 'Mujer negra' es esclarecedora. En este caso la revancha es rápida; el amo aristocrático es matado con precisión extremada por su semejante, un "impecable lord inglés", desenlace claro que concuerda con la ausencia de ambigüedad en sus relaciones con la esclava. El tema del desquite asimismo se plasma en la película de Solás, donde la venganza de la primera Lucía que mata a puñaladas a su amante traicionero se realiza en el ámbito personal. Lamentablemente, la locura es la consecuencia psicológica que sufre Lucía por su imprudencia y debilidad. Esto se opone a la venganza con su potencialidad liberadora contemplada por la protagonista de 'Amo a mi amo'. A pesar de la relación entre las dos mujeres en cuanto al amor (aun cuando éste se diga equivocado) que les da un rasgo humano, sólo Lucía se deja cegar por un amor que la lleva a traicionar a su gente. Para el cineasta y la poeta no es un crimen amar al enemigo, pero no hay perdón para quien lo hace en perjuicio del bienestar colectivo.

Los estudios de la esclavitud tienden a oponer la sumisión de los esclavos domésticos a la actitud más reacia de sus homólogos de las plantaciones. En 'Amo a mi amo' Morejón logra concertar los dos polos demostrando otra posibilidad: la de la esclava, contenta en un principio, que se convierte después en rebelde. La representación de las relaciones entre la esclava y su amo por lo tanto da otra perspectiva del estereotipo de la esclava doméstica obediente e incluso traidora, y ayuda a conciliar la oposición entre casa y campo como escenarios de la esclavitud. La autora sugiere con esto la posibilidad de que el buen tratamiento no garantiza lealtad. El trato amoroso entre los dos queda viciado por la crueldad del amo para con los demás esclavos. Obligada por la llamada de los tambores y de las campanas, la mujer se convertirá en vengadora sin piedad. Pero la historia se esfuma (apropiadamente) al final con los puntos suspensivos que aluden a una acción contemplada en lugar de una solución definida. Y quizás no haya necesidad de una solución porque el poema se refiere sobre todo a procesos

Revista Iberoamericana, Vol. LXXVII, Núm. 235, Abril-Junio 2010, $425-439$
ISSN 0034-9631 (Impreso) 
psíquicos. Lo que destaca esta perspectiva son las ambigüedades inquietantes de la esclavitud, que sirven para mediatizar la historia tradicional de explotación, conflicto, adaptación o resistencia sin complicaciones.

Retomando la conexión entre la película y los poemas se notan otros puntos de convergencia y divergencia. Las fechas grabadas en la pantalla al principio de la historia de cada mujer indican el contexto histórico cambiante necesario para la interpretación de la película. Aparte de las interrupciones que esto implica para el argumento, esta estructura segmentada crea un sentido de disociación entre las tres Lucías. Los acontecimientos de la película que se desarrollan alrededor de estas fechas llegan a ser más memorables que las mismas protagonistas. Además, Solás recurre a la solución extrema de excluir la participación directa e históricamente documentada de mujeres heroicas en las luchas políticas de Cuba, optando por enfocar en mujeres que se destacan por su falta de participación o su aporte marginal en el mejor de los casos y, en el peor, por su papel perjudicial en estos conflictos. En su análisis del significado histórico de la película, Barbara Weinstein la considera deficiente según las normas feministas. “All three women”, observa, “appear politically passive, despite being surrounded by intense political activity; each is a beneficiary of historical events, but not one has an active hand in making that history, except inadvertently" (127). Lejos de encontrarse al margen de la política (como la Lucía de 1895), o de desempeñar un papel secundario (como su sucesora de 1932), o de deber su potentización a otros (como la última Lucía), la mujer afrocubana de 'Mujer negra' se constituye sobre todo como creadora o co-creadora de la historia cubana. Weinstein cita los numerosos ejemplos de mujeres que, a despecho de lo que da a entender la película, se han dedicado al activismo político y social a lo largo de la historia cubana. Pero no deja de advertir de modo particular que la película precede a la explosión del movimiento feminista en los años setenta, el cual dio lugar a la revaloración del papel histórico de la mujer. En cambio, Morejón escribía bajo condiciones más propicias en 1975 y 1986. Como beneficiaria de las posibilidades interpretativas brindadas por el pensamiento feminista y poscolonial, disponía de ideologías subversivas que le permitieron ofrecer alternativas a la visión dominante del papel histórico femenino.

La protagonista de 'Mujer negra', presentada primero como mujer africana esclavizada, se une sin interrupción con sus descendientes de cada generación posterior. La resistencia, la industria y un arraigado nacionalismo son el sello distintivo de esta mujer al transformarse en afrocubana. La poeta centra la atención en su espíritu rebelde y sus actos constructivos que aseguran su supervivencia. Morejón parece demostrar que la resistencia, abierta o secreta, sea en forma tangible o simbólica, ha sido una cualidad ineluctable de la mujer cubana de origen africano: "me rebelé,... me sublevé, me fui al monte .....bajé de la Sierra” (46-47). Es un proceso largo que comienza

\footnotetext{
Revista Iberoamericana, Vol. LXXVII, Núm. 235, Abril-Junio 2010, $425-439$
ISSN 0034-9631 (Impreso)
} 
con la ruptura consciente de los lazos con el pasado africano y que termina con su participación en la insurrección castrista.

En la historia de la Lucía de 1895 el cineasta reconoce sólo de paso la contribución de las mujeres al conflicto. Desde el punto de vista ideológico, la identificación de esta Lucía con la política anticolonial no va más allá del amor y apoyo emocional que le brinda a Felipe, su hermano rebelde. No sólo se encuentra al margen de la acción política, sino que bajo la influencia de su amor ciego por Rafael, su amante español, Lucía se convierte en estorbo a la causa de las fuerzas independentistas cuyo fracaso se atribuye a su traición involuntaria en la película. ${ }^{4}$

Desde tal punto de vista, a esta Lucía se le puede considerar como una versión cubana de la polémica Malinche azteca, criticada por algunos por su contribución igualmente traidora a la conquista española de México. La mirada desconcertada de Lucía al encontrarse de pie en medio del combate entre las tropas españolas y cubanas gráficamente transmite la imagen de una mujer alejada del proceso político, viviendo una historia en la cual no ha tomado parte y que no llega a comprender.

Solás no pasa por alto la contribución afrocubana a la guerra independentista, pero reconoce sólo la intervención heroica de los soldados negros. Con 'Mujer negra', Morejón desecha la idea de que el heroísmo en el campo de batalla fue solamente cosa de hombres y que las mujeres desempeñaron un papel secundario. Su poema, por ende, celebra el heroísmo olvidado de la desconocida mambisa (guerrera) afrocubana cuando su personaje se presenta cabalgando entre las tropas encabezadas por el líder afrocubano Antonio Maceo durante dicha guerra. Dado que Maceo fue acusado en un principio de promover una guerra racial (Lewis 294), este detalle es un índice significativo de la sensibilidad étnica que sirve de base al poema.

La segunda Lucía se incorpora al grupo de mujeres en las manifestaciones callejeras contra la dictadura de Machado, pero su meta es asumir la misión política de Aldo, su marido activista, según lo confiesa ella misma: "Yo cojo el camino que tú escojas". Como su antecesora a quien la decepción del amante conduce a la locura, su colapso mental al morirse Aldo pone de relieve su vulnerabilidad psicológica. Esto dista mucho de la autonomía instintiva y la fortaleza psicológica de la afrocubana dueña de sí misma que encontramos en 'Mujer negra'.

La costura clandestina de ropa para los soldados independentistas en la película se puede calificar como un acto subversivo y una contribución fructífera de las

4 Weinstein considera esta traición una distorsión de la realidad histórica de las guerreras (mambisas) que participaron en la lucha o que cuidaron a los heridos en el campo de batalla o que fueron trasladadas a los campos de concentración. Muchas eran víctimas de la guerra, pero no se volvieron locas. Al contrario huyeron de los españoles al territorio de los rebeldes para arropar y alimentar a los soldados y recolectaron fondos para el movimiento (130). Para un estudio más detallado del papel de las mambisas véase el artículo de Stoner y el libro de Prados-Torreira.

ISSN 0034-9631 (Impreso) 
mujeres cubanas del siglo diecinueve. Sin embargo, la inconsciencia y frivolidad con que emprenden esta tarea no se acerca al trabajo consciente e intencionado de la mujer negra emblemática de Morejón. Como actividad femenina, la costura también aparece en 'Mujer negra' donde la obligación laboral de la mujer (coser la casaca de Su Merced) no se separa de la obligación sexual (parirle un hijo macho). Por otra parte, donde la película presenta la costura como única función laboral de la mujer de la clase privilegiada, los deberes de la protagonista del poema no quedan limitados a su papel doméstico.

A la perspectiva de grandes momentos históricos que ofrece la película de Solás, Morejón contrapone un enfoque más global en el que incluye tanto los momentos ordinarios y quehaceres cotidianos como los grandes eventos políticos e históricos. Su personaje es, por lo tanto, figura compuesta de la mujer africana esclavizada que trabaja en el espacio doméstico, y de su hermana que trabaja en los campos (plantando, cosechando, etc.). En la imaginación histórica de Morejón no se le da mayor importancia a su papel de colaboradora activa en las luchas por la independencia que a las faenas más humildes de la mujer como, por ejemplo, construir el barracón durante la época esclavista. El nacionalismo del afrocubano es un capítulo de la historia cubana una vez pasado por alto pero ahora bien documentado. Con ‘Mujer negra’ Morejón intentó llenar este espacio realzando el trabajo físico de la mujer (interpretado mayormente como quehacer nacionalista):

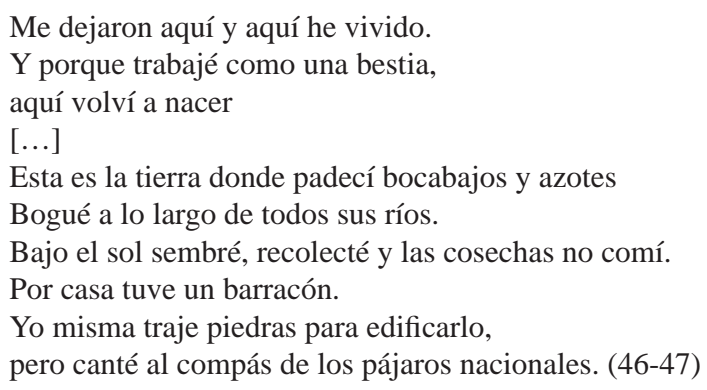

La conexión entre nacer y nación es obvia. El nacionalismo de la mujer negra es inseparable de su identidad personal. Además, ha sabido asumir el sufrimiento no como destino ineluctable de una víctima sino como algo necesario para lograr los fines deseados.

Aunque la película no incluye a la mujer esclavizada de una manera directa, su presencia indirecta se siente en una referencia metafórica en la historia de la Lucía de la época posrevolucionaria. La esclavitud se invoca para caracterizar la dominación masculina de la mujer como condición que se debe rechazar -esclava es lo que la

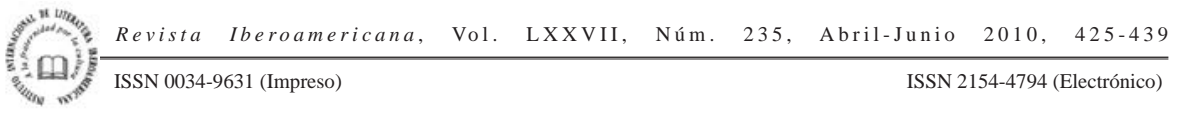


mujer nueva de la revolución no es para su marido-. Al final, la recién alfabetizada Lucía rehúsa el cautiverio de su esposo Tomás con las palabras "me boy, yo no soy esclaba". El coro de sus compañeras de trabajo repite la idea ("la mujer no es esclava del marido"), afirmando los derechos femeninos como beneficio colateral de la revolución. La emancipación a la cual se refiere esta metáfora resuena aún más en 'Mujer negra', donde la liberación de la mujer africana de la esclavitud real pesa más que el librarse la mujer de los grillos metafóricos del patriarcado en la nueva sociedad revolucionaria.

En cada poema, como en el segmento final de la película, se encuentran muestras ineludibles de la doctrina socialista revolucionaria. El tratamiento brutal de los otros esclavos en 'Amo a mi amo' más que una experiencia personal, es lo que sirve de estímulo psicológico para despertar la conciencia social de la mujer esclavizada y para impulsarla a concebir la venganza física como su deber social a sus semejantes. Su recién suscitada empatía con el sufrimiento de éstos viene a ser catalizador para su rebelión. En cambio, las luchas del personaje de 'Mujer negra' son actividades que se emprenden a solas hasta llegar a la lucha revolucionaria. Celebrar la revolución como empresa colectiva y elogiar la comunidad igualitaria como signos del nuevo orden político socialista es el clímax al que se aproxima el poema. El "yo" se funde con el "nosotros" al ceder el ser individual a la identidad colectiva:

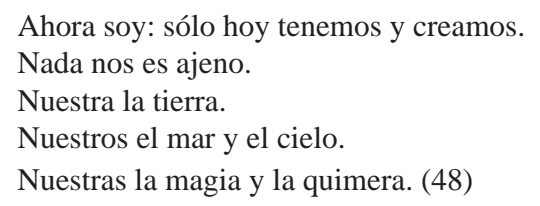

La mujer afrocubana no se destaca en la película hasta el segmento final. Al salir de la sombra se presenta como ejemplo del nuevo sujeto revolucionario preparado para predicar el evangelio de la revolución. Este segmento se centra tanto en Angelina, vocera revolucionaria afrocubana, como en la tercera Lucía, guajira cuyo mestizaje aparenta india más que africana. La actuación bulliciosa de Angelina como defensora principal de los ideales de la revolución en este segmento marca el final del silencio de la mujer afrocubana. Sólo la revolución, la película parece alegar, pudo poner fin a su exclusión social y conseguir la asunción de poder de la mujer afrocubana. Invisible antes de la revolución, se identifica ahora como integrante imprescindible de una comunidad de mujeres unidas en la lucha contra la dominación masculina, una lucha posibilitada por la revolución. Como heredera de la revolución y participante activa en el nuevo orden socioeconómico, esta mujer no necesita luchar en el campo político; ya se ha ganado la batalla. Su único papel ahora es proteger los logros revolucionarios ante los peligros domésticos.

ISSN 0034-9631 (Impreso) 
A la mujer negra de Morejón no se le concedió tal lujo; con ella todo se ha logrado con duro esfuerzo. Esta mujer se presenta como coparticipante con Fidel en la luchas de la revolución:

bajé de la Sierra

para acabar con capitales y usureros

con generales y burgueses. (47-48)

Lo que goza bajo dicha revolución, por ende, son los frutos de su labor (ahora colectiva):

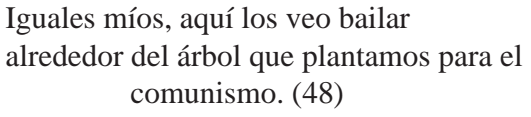

Mientras que reconoce y le acredita a la revolución los bienes políticos y sociales, la autora se esmera en presentar los beneficios como culminación de un proceso de lucha asumida por la mujer negra cubana a partir del momento de la llegada de su antecesora africana al Caribe.

\section{CONCLUSIÓN}

Según Natalie Zemon Davis "[History] is not about confirming what you already know, but about stretching it and turning it upside down and then reaffirming some values, or putting some into question” (citado por Stevens 7). Al igual que la película de Solás, los poemas de Morejón no pretenden encerrar validez histórica absoluta; los tres, sin embargo, son meditaciones sobre la historia. Sirven, por consiguiente, no tanto para reafirmar las versiones existentes de la historia cubana sino para interrogarlas. El panorama creado en 'Amo a mi amo' que va en contra de la convención literaria antiesclavista es susceptible de ser interpretado como defensa de una de las prácticas más inicuas de la esclavitud. Sin embargo, este episodio, filtrado a través de un prisma posmoderno, adquiere otro significado; al enfocar en el romance recíproco en vez de la violencia sexual, la autora subvierte la ideología esclavista de separatismo racial, lo cual representa un golpe antiesclavista tan severo como el efectuado por la historia más ubicua de violación sexual. Ninguna de las dos protagonistas poéticas manifiesta la psicología de víctima. La resistencia (la capacidad de recuperarse pronto después de una experiencia difícil) y la volición (el poder de escoger libremente y tomar decisiones autónomas) son los rasgos que las definen.

Con la disolución de algunas de las fronteras que separan la historia (realidad) de la literatura (ficción), los historiadores ahora recurren a fuentes no documentales de información sobre la vida del pasado. Las representaciones de Morejón son una

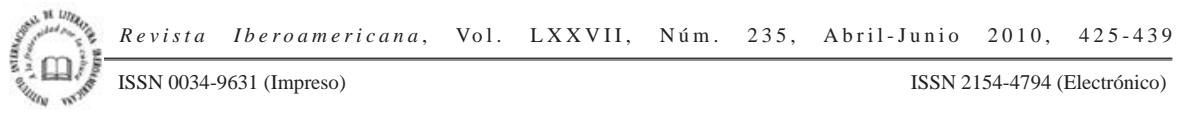


advertencia de que, como se está reconociendo cada vez más, la historia de los caribeños de origen africano no ha sido uniforme. Nos recuerdan igualmente que las versiones históricas que se niegan a reconocer excepciones, que dejan de hacerlo o que tratan exclusivamente de lo que se juzga lo normal o lo dominante son un género de ficción.

\section{BiBLIOGRAFÍA}

DeCosta-Willis, Miriam, ed. Singular Like a Bird: The Art of Nancy Morejón. Washington, D.C.: Howard UP, 1999.

James, Conrad. "Patterns of Resistance in Afro-Cuban Women's Writing: Nancy Morejón's 'Amo a mi amo'”. Framing the Word:Gender and Genre in Caribbean Women's Writing. Joan Anim-Addo, ed. Londres: Whiting and Birch Ltd., 1996. 159-68.

Klages, Mary. Literary Theory: A Guide for the Perplexed. Londres: Continuum International, 2006.

Lewis, Gordon K. Main Currents in Caribbean Thought. Baltimore: Johns Hopkins UP, 1983.

Morejón, Nancy. Richard trajo su flauta y otros poemas. Mario Benedetti, ed. Madrid: Visor, 1999.

Prados-Torreira, Teresa. Mambisas: Rebel Women in Nineteenth-Century Cuba. Gainesville: UP of Florida, 2005.

Stoner, K. Lynn. "Militant Heroines and the Consecration of the Patriarchal State: The Glorification of Loyalty, Combat, and National Suicide in the Making of Cuban National Identity.” Cuban Studies 34 (2003): 71-95.

Suárez y Romero, Anselmo. Francisco [1838]. La Habana: Instituto Cubano del Libro, 1974.

Tanco y Bosmeniel, Félix. Petrona y Rosalía [1838]. La Habana: Letras Cubanas, 1980. Weinstein, Barbara. "Lucía: Inventing Women’s History on Film”. Based on a True Story: Latin American History at the Movies. Donald Stevens, ed. Wilmington, DE: SR, 1997. 123-42.

Zambrana, Antonio. El negro Francisco [1875]. La Habana: Letras Cubanas, 1979.

Revista Iberoamericana, Vol. LXXVII, Núm. 235, Abril-Junio 2010, $425-439$
ISSN 2154-4794 (Electrónico) 
